\title{
GENDER DIFFERENCES BETWEEN THE PERCEPTIONS OF PHYSICS AND SCIENCE IN GENERAL AMONGST SENIOR AND JUNIOR STUDENTS AT A SOUTH AFRICAN UNIVERSITY
}

\author{
Leelakrishna Reddy \\ Department of Physics, University of Johannesburg, Johannesburg (South Africa)
}

\begin{abstract}
It is widely accepted from literature (Agra et al., 2017) that male students outperform their female counterparts in science, and in particular physics. Accordingly, gender differences stem from their prior backgrounds in mathematics, physics and differences about their attitudes and beliefs about the subject. To measure students' differences in perceptions regarding physics and science, use is made of a questionnaire that is comprised of two sections, A (four questions) and B (fifteen questions). In section A students were required to respond to questions that relates to their relationship between life and physics, chemistry and mathematics, while in section B, a probe is made regarding their confidence in physics and chemistry. A total of 101 students participated in this study, ranging from junior students (62 emergency medical care and podiatry students) to senior students (37 analytical chemistry fourth year students). Results are presented in both numeric and in percentage form. The fundamental difference between the genders is that in both groups there appears to be a strong affinity for chemistry for the female students, and even a stronger liking for chemistry by the senior analytical chemistry students. The males on the other hand shown an average liking for chemistry in both cohorts, but a slightly better liking for physics as a subject. From this anecdotal study, it appears that females show more preferences for science and chemistry than their male counterparts.
\end{abstract}

Keywords: Physics, gender, chemistry, anecdotal, questionnaire.

\section{Introduction}

Physics as a subject is important for any country's welfare and technological advancement (Baran, 2016). Thus, the contribution by physicist is of paramount importance for any growing scientific economy. The lack of which can be detrimental for any technological endeavors. In this case, it can be said that equal contribution by both males and females to science would be any ideal scenario. However, research points to the converse of this scenario. This stems from the fact that physics is considered a difficult subject and thus there are variations in perceptions between males and females. Accordingly females' lack of interest in the subject, results in them showing less enthusiasm for the subject (Baran, 2016; Bamidele, 2001). Research by Visser (2007) and Ozgun Koca \& Sen (2011) revealed that males preferred physics more than their female counterparts. In the same vein, research by Wei-Zho Shi (2012) reveals a very different scenario for Chinese students. He found that female students preferred physics learning by relating and by analysis and this correlated to their better understanding in the subject, while the males preferred to study physics by rote learning, and this resulted in a negative correlation in their performance. In comparison to research done by Kessel et al. (2006), they found that male students preferred physics more than their female counterparts. Because of this, they found that females were not interested in physics and were lesser successful in the subject (Baran, 2016). This correlates well with the research done by Saleh (2014), who indicated that females experienced a higher level of difficulty in understanding physics. In the same token, research done by Zavale et al. (2015), points towards to students generally failing first year physics and mathematics courses. This unfolds because they do not see the relevance of physics and mathematics as part of their professional career progression. In this respect, this research aims to shed more light on students' perception of physics and science in general with respect to gender between senior and junior students at a South African university. It is hoped that this research will fill a gap in understanding of how student's pre-knowledge of physics from their high school studies would change through their progression of their studies at university. 


\section{Methodology}

This study was undertaken to measure students' perception of physics and science in general as function of gender between the junior and senior students at a South African university. To measure such perceptions, use is made of a questionnaire developed by Keith Wurtz (2007) for this study. This questionnaire consists of two parts; with section A (comprised of 4 questions) and section B (comprised of 15 questions). Section A probes the students' relationship to science (mathematics, physics and chemistry) and section B probes their confidence with respect to chemistry and physics. A total of 101 students participated in this study, comprising of juniors (27 males and 37 females) from the Emergency and Medical Care and Podiatry departments, while the senior students (12 males and 25 females) came from the Analytical Chemistry department. These students were studying physics (non-major) as part of their curricular studies. Results are expressed in both numeric and percentage form. Prior to the start of this research, permission was sought from each of the above groups of students to conduct the research. Further, an explanation was provided as why such a project was undertaken. The survey took no more than 10 minutes to complete. The students were required to respond to each of the questions of the questionnaire on a rating scale of between +1 (Disagree) to +6 (Agree). For convenience, the rating scores of the following were combined: $(+1,+2),(+3,+4)$ and $(+5,+6)$.

\section{Results and discussions}

The results of the students' perception about physics and science in general are presented in tables 1 to 4 , with tables 1 and 2 referring to the junior students while tables 3 and 4 refers to the senior students.

Table 1. Comparisons of the junior students' perceptions about their relationship between their lives and physics, mathematics and chemistry.

\begin{tabular}{|c|c|c|c|c|c|c|c|}
\hline \multirow[t]{2}{*}{ No } & \multirow[t]{2}{*}{ Description } & \multicolumn{3}{|c|}{ Males } & \multicolumn{3}{|c|}{ Females } \\
\hline & & $\begin{array}{l}+1 \text { and } \\
+2\end{array}$ & $\begin{array}{l}+3 \text { and } \\
+4\end{array}$ & $\begin{array}{l}+5 \text { and } \\
+6\end{array}$ & $\begin{array}{l}+1 \text { and } \\
+2\end{array}$ & $\begin{array}{l}+3 \text { and } \\
+4\end{array}$ & $\begin{array}{l}+5 \text { and } \\
+6\end{array}$ \\
\hline \multirow[t]{2}{*}{1} & \multirow{2}{*}{$\begin{array}{l}\text { I understand the relationship between my life } \\
\text { and physics }\end{array}$} & 0 & 2 & 25 & 0 & 22 & 15 \\
\hline & & $0 \%$ & $8 \%$ & $59 \%$ & $0 \%$ & $59 \%$ & $41 \%$ \\
\hline \multirow[t]{2}{*}{2} & \multirow{2}{*}{$\begin{array}{l}\text { I understand the relationship between my life } \\
\text { and chemistry }\end{array}$} & 0 & 7 & 20 & 1 & 17 & 19 \\
\hline & & $4 \%$ & $37 \%$ & $59 \%$ & $3 \%$ & $46 \%$ & $51 \%$ \\
\hline \multirow[t]{2}{*}{3} & \multirow{2}{*}{$\begin{array}{l}\text { Math is important to the understanding of } \\
\text { science }\end{array}$} & 0 & 1 & 26 & 1 & 2 & 34 \\
\hline & & $0 \%$ & $4 \%$ & $96 \%$ & $3 \%$ & $5 \%$ & $92 \%$ \\
\hline \multirow[t]{2}{*}{4} & \multirow[t]{2}{*}{ I am confident in my mathematics ability } & 0 & 7 & 20 & 2 & 14 & 21 \\
\hline & & $0 \%$ & $26 \%$ & $74 \%$ & $5 \%$ & $38 \%$ & $57 \%$ \\
\hline
\end{tabular}

Table 2. Comparison of the junior students' perception about their confidence in physics and chemistry.

\begin{tabular}{|c|c|c|c|c|c|c|c|}
\hline \multirow[t]{2}{*}{ No } & \multirow[t]{2}{*}{ Description } & \multicolumn{3}{|c|}{ Males } & \multicolumn{3}{|c|}{ Females } \\
\hline & & $\begin{array}{l}+1 \text { and } \\
+2\end{array}$ & $\begin{array}{l}+3 \text { and } \\
+4\end{array}$ & $\begin{array}{l}+5 \text { and } \\
+6\end{array}$ & $\begin{array}{l}+1 \text { and } \\
+2\end{array}$ & $\begin{array}{l}+3 \text { and } \\
+4\end{array}$ & $\begin{array}{l}+5 \text { and } \\
+6\end{array}$ \\
\hline \multirow[t]{2}{*}{1} & \multirow[t]{2}{*}{ The parts of an atom } & 1 & 4 & 27 & 2 & 9 & 26 \\
\hline & & $4 \%$ & $15 \%$ & $82 \%$ & $5 \%$ & $24 \%$ & $70 \%$ \\
\hline \multirow[t]{2}{*}{2} & \multirow[t]{2}{*}{ Static electricity } & 1 & 10 & 16 & 4 & 21 & 12 \\
\hline & & $4 \%$ & $37 \%$ & $59 \%$ & $11 \%$ & $57 \%$ & $32 \%$ \\
\hline \multirow[t]{2}{*}{3} & \multirow[t]{2}{*}{ How atoms form compounds } & 1 & 6 & 20 & 0 & 16 & 21 \\
\hline & & $4 \%$ & $23 \%$ & $74 \%$ & $0 \%$ & $43 \%$ & $57 \%$ \\
\hline \multirow[t]{2}{*}{4} & \multirow[t]{2}{*}{ Inertia } & 0 & 5 & 22 & 2 & 8 & 27 \\
\hline & & $0 \%$ & $19 \%$ & $82 \%$ & $5 \%$ & $22 \%$ & $73 \%$ \\
\hline \multirow[t]{2}{*}{5} & \multirow[t]{2}{*}{ How iron forms rust } & 3 & 9 & 15 & 2 & 16 & 19 \\
\hline & & $11 \%$ & $33 \%$ & $56 \%$ & $5 \%$ & $43 \%$ & $51 \%$ \\
\hline \multirow[t]{2}{*}{6} & \multirow[t]{2}{*}{ Simple machines } & 1 & 10 & 16 & 2 & 17 & 18 \\
\hline & & $4 \%$ & $37 \%$ & $59 \%$ & $5 \%$ & $46 \%$ & $49 \%$ \\
\hline \multirow[t]{2}{*}{7} & \multirow[t]{2}{*}{ How atoms forms ions } & 1 & 11 & 15 & 2 & 11 & 24 \\
\hline & & $4 \%$ & $40 \%$ & $56 \%$ & $5 \%$ & $30 \%$ & $65 \%$ \\
\hline \multirow[t]{2}{*}{8} & \multirow[t]{2}{*}{ Magnetism } & 3 & 8 & 16 & 3 & 13 & 21 \\
\hline & & $11 \%$ & $33 \%$ & $59 \%$ & $8 \%$ & $35 \%$ & $57 \%$ \\
\hline \multirow[t]{2}{*}{9} & \multirow{2}{*}{$\begin{array}{l}\text { The difference between organic and inorganic } \\
\text { compounds }\end{array}$} & 1 & 5 & 21 & 2 & 4 & 31 \\
\hline & & $4 \%$ & $19 \%$ & $77 \%$ & $5 \%$ & $11 \%$ & $84 \%$ \\
\hline \multirow[t]{2}{*}{10} & \multirow{2}{*}{$\begin{array}{l}\text { The relationship between magnetism and } \\
\text { electricity }\end{array}$} & 3 & 12 & 12 & 2 & 17 & 18 \\
\hline & & $11 \%$ & $45 \%$ & $45 \%$ & $5 \%$ & $46 \%$ & $49 \%$ \\
\hline
\end{tabular}




\begin{tabular}{|c|l|c|c|c|c|c|c|}
\hline 11 & The different states of matter & 2 & 7 & 18 & 1 & 5 & 31 \\
\cline { 3 - 7 } & & $7 \%$ & $29 \%$ & $67 \%$ & $3 \%$ & $14 \%$ & $84 \%$ \\
\hline 12 & \multirow{2}{*}{ How sound moves through air } & 0 & 11 & 16 & 3 & 13 & 21 \\
\cline { 3 - 8 } & & $0 \%$ & $41 \%$ & $59 \%$ & $8 \%$ & $35 \%$ & $57 \%$ \\
\hline 13 & Acidic and basic compounds & 0 & 8 & 19 & 2 & 7 & 28 \\
\cline { 3 - 8 } & & $0 \%$ & $30 \%$ & $70 \%$ & $5 \%$ & $19 \%$ & $76 \%$ \\
\hline \multirow{2}{*}{14} & How heat is transferred from one substance to & 0 & 11 & 16 & 1 & 21 & 15 \\
\cline { 3 - 8 } & another & $0 \%$ & $40 \%$ & $60 \%$ & $3 \%$ & $57 \%$ & $41 \%$ \\
\hline & How batteries form electricity & 2 & 14 & 11 & 2 & 27 & 8 \\
\hline & The properties of light & $7 \%$ & $52 \%$ & $41 \%$ & $5 \%$ & $73 \%$ & $22 \%$ \\
\hline
\end{tabular}

Table 3. Comparisons of the senior students' perceptions about their relationship between their lives and physics, mathematics and chemistry. Order of presentation is females first followed by males.

\begin{tabular}{|c|c|c|c|c|c|c|c|}
\hline \multirow[t]{2}{*}{ No } & \multirow[t]{2}{*}{ Description } & \multicolumn{3}{|c|}{ Females } & \multicolumn{3}{|c|}{ Males } \\
\hline & & $\begin{array}{l}+1 \text { and } \\
+2\end{array}$ & $\begin{array}{c}+3 \text { and } \\
+4\end{array}$ & $\begin{array}{c}+5 \text { and } \\
+6\end{array}$ & $\begin{array}{c}+1 \text { and } \\
+2\end{array}$ & $\begin{array}{c}+3 \text { and } \\
+4\end{array}$ & $\begin{array}{l}+5 \text { and } \\
+6\end{array}$ \\
\hline \multirow[t]{2}{*}{1} & \multirow{2}{*}{$\begin{array}{l}\text { I understand the relationship between my life } \\
\text { and physics }\end{array}$} & 1 & 17 & 7 & 4 & 4 & 4 \\
\hline & & $4 \%$ & $68 \%$ & $28 \%$ & $33 \%$ & $34 \%$ & $33 \%$ \\
\hline \multirow[t]{2}{*}{2} & \multirow{2}{*}{$\begin{array}{l}\text { I understand the relationship between my life } \\
\text { and chemistry }\end{array}$} & 0 & 2 & 23 & 0 & 0 & 12 \\
\hline & & $0 \%$ & $8 \%$ & $92 \%$ & $0 \%$ & $0 \%$ & $100 \%$ \\
\hline \multirow[t]{2}{*}{3} & \multirow{2}{*}{$\begin{array}{l}\text { Math is important to the understanding of } \\
\text { science }\end{array}$} & 1 & 6 & 18 & 0 & 2 & 10 \\
\hline & & $4 \%$ & $24 \%$ & $72 \%$ & $0 \%$ & $16 \%$ & $84 \%$ \\
\hline \multirow[t]{2}{*}{4} & \multirow[t]{2}{*}{ I am confident in my mathematics ability } & 2 & 16 & 7 & 1 & 3 & 8 \\
\hline & & $8 \%$ & $64 \%$ & $28 \%$ & $8 \%$ & $25 \%$ & $67 \%$ \\
\hline
\end{tabular}

Table 4. Comparison of the senior students' perception about their confidence in physics and chemistry.

\begin{tabular}{|c|c|c|c|c|c|c|c|}
\hline \multirow[t]{2}{*}{ No } & \multirow[t]{2}{*}{ Description } & \multicolumn{3}{|c|}{ Females } & \multicolumn{3}{|c|}{ Males } \\
\hline & & $\begin{array}{l}+1 \text { and } \\
+2\end{array}$ & $\begin{array}{c}+3 \text { and } \\
+4\end{array}$ & $\begin{array}{l}+5 \text { and } \\
+6\end{array}$ & $\begin{array}{l}+1 \text { and } \\
+2\end{array}$ & $\begin{array}{c}+3 \text { and } \\
+4\end{array}$ & $\begin{array}{l}+5 \text { and } \\
+6\end{array}$ \\
\hline \multirow[t]{2}{*}{1} & \multirow[t]{2}{*}{ The parts of an atom } & 0 & 5 & 20 & 1 & 3 & 8 \\
\hline & & $0 \%$ & $20 \%$ & $80 \%$ & $8 \%$ & $25 \%$ & $67 \%$ \\
\hline \multirow[t]{2}{*}{2} & \multirow[t]{2}{*}{ Static electricity } & 1 & 19 & 5 & 2 & 4 & 6 \\
\hline & & $4 \%$ & $76 \%$ & $20 \%$ & $17 \%$ & $33 \%$ & $50 \%$ \\
\hline \multirow[t]{2}{*}{3} & \multirow[t]{2}{*}{ How atoms form compounds } & 0 & 4 & 21 & 1 & 3 & 8 \\
\hline & & 05 & $16 \%$ & $84 \%$ & $8 \%$ & $25 \%$ & $67 \%$ \\
\hline \multirow[t]{2}{*}{4} & \multirow[t]{2}{*}{ Inertia } & 0 & 15 & 10 & 1 & 4 & 7 \\
\hline & & $0 \%$ & $60 \%$ & $40 \%$ & 85 & $34 \%$ & $58 \%$ \\
\hline \multirow[t]{2}{*}{5} & \multirow[t]{2}{*}{ How iron forms rust } & 0 & 5 & 20 & 0 & 4 & 8 \\
\hline & & $0 \%$ & $20 \%$ & $80 \%$ & $0 \%$ & $33 \%$ & $67 \%$ \\
\hline \multirow[t]{2}{*}{6} & \multirow[t]{2}{*}{ Simple machines } & 1 & 15 & 9 & 1 & 6 & 5 \\
\hline & & $4 \%$ & $60 \%$ & $36 \%$ & $8 \%$ & $50 \%$ & $42 \%$ \\
\hline \multirow[t]{2}{*}{7} & \multirow[t]{2}{*}{ How atoms forms ions } & 0 & 4 & 21 & 1 & 3 & 8 \\
\hline & & $0 \%$ & $16 \%$ & $84 \%$ & $8 \%$ & $25 \%$ & $67 \%$ \\
\hline \multirow[t]{2}{*}{8} & \multirow[t]{2}{*}{ Magnetism } & 0 & 12 & 13 & 3 & 3 & 6 \\
\hline & & $0 \%$ & $48 \%$ & $52 \%$ & $25 \%$ & $25 \%$ & $50 \%$ \\
\hline \multirow[t]{2}{*}{9} & \multirow{2}{*}{$\begin{array}{l}\text { The difference between organic and inorganic } \\
\text { compounds }\end{array}$} & 0 & 2 & 23 & 0 & 1 & 11 \\
\hline & & $0 \%$ & $8 \%$ & $92 \%$ & $0 \%$ & $8 \%$ & $92 \%$ \\
\hline \multirow[t]{2}{*}{10} & \multirow{2}{*}{$\begin{array}{l}\text { The relationship between magnetism and } \\
\text { electricity }\end{array}$} & 0 & 14 & 11 & 2 & 5 & 5 \\
\hline & & $0 \%$ & $56 \%$ & $44 \%$ & $17 \%$ & $41 \%$ & $42 \%$ \\
\hline \multirow[t]{2}{*}{11} & \multirow[t]{2}{*}{ The different states of matter } & 0 & 2 & 23 & 1 & 2 & 9 \\
\hline & & $0 \%$ & $8 \%$ & $92 \%$ & 85 & 175 & $75 \%$ \\
\hline \multirow[t]{2}{*}{12} & \multirow[t]{2}{*}{ How sound moves through air } & 1 & 7 & 17 & 0 & 7 & 5 \\
\hline & & $4 \%$ & $28 \%$ & $68 \%$ & $0 \%$ & $58 \%$ & $42 \%$ \\
\hline 13 & Acidic and basic compounds & 0 & 4 & 21 & 0 & 1 & 11 \\
\hline & & $0 \%$ & $16 \%$ & $84 \%$ & 0 & $8 \%$ & $92 \%$ \\
\hline 14 & How heat is transferred from one substance to & 0 & 4 & 21 & 0 & 3 & 9 \\
\hline & another & $0 \%$ & $16 \%$ & $84 \%$ & $0 \%$ & $25 \%$ & $75 \%$ \\
\hline 15 & How batteries form electricity & 1 & 10 & 14 & 2 & 2 & 8 \\
\hline & & $4 \%$ & $40 \%$ & $56 \%$ & $17 \%$ & $16 \%$ & $67 \%$ \\
\hline 16 & The properties of light & 0 & 7 & 18 & 1 & 5 & 6 \\
\hline & & $0 \%$ & $28 \%$ & $72 \%$ & $8 \%$ & $41 \%$ & $51 \%$ \\
\hline
\end{tabular}




\subsection{Gender comparisons of the perceptions of physics and science in general amongst junior students}

In table 1, we see a strong relationship between the student's life and chemistry for both genders (item 3, 96\% for males and $92 \%$ for females) of this study. As a result of this, everything that unfolds from this research is an inclination for chemistry related topics. This is reflected in item 2 of the questionnaire where the perceptions of both genders are given (item 2, 59\% for males and $51 \%$ for females). Of note is that male students show a stronger inclination for mathematics as a subject than physics.

In table 2, a similar trend unfolds for both males and females in that they show stronger preference for chemistry related topics. In this regard, males have a stronger preference for topics such as the "parts of an atom" (item 1, 82\%) and a sound foundational understanding of the differences between "organic and inorganic chemistry" (item 9, 77\%). By comparison, to the females, they also have a strong preference for the latter topic (item 9, 84\%) and for a sound understanding of the different states of matter in chemistry (item 11,84\%). Both genders appear to have a moderate understanding of the relationships between magnetism and electricity (item 10, $45 \%$ for males and $49 \%$ for females) in physics. Of particular interest, for some reason males appear to have a good understanding of the topic "inertia" in physics (item 4, 82\%). It is also not surprising to see students (both genders) preference for acids and bases (item 13, 70\% for males and 76\% for females) when their field of study is not in chemistry. For the female students, it is observed that they have a moderate preference for topics in physics, and in particular of for how electricity is obtained from battery power (item 15, 22\%) and the properties of light $(16,35 \%)$.

\subsection{Gender comparisons of the perceptions of physics and science in general amongst senior students}

The results of table 3 indicates that senior students have a good association of chemistry and find meaning of it in their lives (item 2, 100\% for males and 92\% for females). They also realize that mathematics is crucial for their understanding of science (item 3, 84\% for males and $72 \%$ for females). Their low preference for physics (item 1,33\% for males and 28\% for females) is in keeping of their preferred choice of chemistry for their studies. In this instance, physics is regarded as an auxiliary (pre-requisite subject) subject (even at the $2^{\text {nd }}$ year level). For these students doing physics is just to understand some related concepts in chemistry better.

From table 4, we see that female students have a strong affinity for chemistry related topics compared to the males. In particular, they have a good knowledge of "parts of an atom" (item 1, 80\%) and how atoms are used to form compounds (item 3, 84\%), what happens to iron when it combines with oxygen (rusting) (item 5, 80\%) and the various states of matter (item 11, 92\%). They also have a good understanding of how atoms forms ions (item 7, 84\%). As far as the males students are concerned, their preference for these topics is quite average (item 1, 67\%), item $3(67 \%)$, item $5(67 \%)$ and item 7 (67\%). One of the items for which both males and females have exactly the same level of preference is item 9 (males $92 \%$ and females $92 \%$ ). For this item, these students appear to have an excellent understanding of the differences between organic and inorganic chemistry, which is very much in keeping with their field of study. With a good background in chemistry, they also show a strong preference for acids and bases (item 13, 92\% for males and $84 \%$ for females). These topics are also done at junior and senior grades at high school. A topic in the questionnaire, which is well covered in basic or general science is the topic "heat transfer" and for this topic their knowledge appears to be good (item 14, 84\% for females). Correspondingly, the male student's preference for items $13(92 \%)$ and $14(75 \%)$ appears to be good as well.

\subsection{Comparisons of the perceptions for physics and science in general between the juniors and seniors}

The seniors, because of their field of study, show a higher preference for chemistry related topics than the juniors. In particular, senior females have a high affinity for chemistry compared to the males. In contrast to the juniors, the males have a greater preference for chemistry than the junior females. Whilst the seniors show limited interest in physics, the juniors appear to show a slightly better interest to physics related topics. In particular, the junior males have a slightly higher preference for science related topics than the females.

\section{Conclusion}

This study was undertaken to determine the students' perception about physics and science in general between the genders amongst junior and senior students at a South African university. Results reveals that both juniors and seniors have a high preference for chemistry, even though the juniors are not specializing in chemistry. In addition, the senior female students have the highest preference for chemistry than both the senior male and junior students. The preference for physics by both cohorts of students is limited and is a cause for concern. Results of this study might be different if students who are pursuing a physics major are tested. 


\section{References}

Agra, E., Fischer, S.M., \& Beilock, S.L. (2017). The Role of Students' Gender and Anxiety in Physics Performance. 2017 PERC Proceedings, 24-27.

Bamidele, O.M.F. (2001). Promoting Science and Mathematics Education amongst females in Nigeria. Presented at the NCCE/UNESCO 5-Day Train the Trainer Workshop for Revitalization of Science Education in Nigeria.

Baran, M. (2016). An Analysis on High School Students' Perceptions of physics Courses in Terms of Gender. Journal of Education and Training Studies, 4(3), 150-160.

Kessel, U., Rau, M., \& Hannover, B. (2006). What goes well with physics? Measuring and altering the image of science. British Journal of Educational Psychology, 76(4), 761-780.

Ozgun-Koca, S.A., \& Sen, A.I. (2011). Evaluation of beliefs and attitudes of high school students towards science and mathematics courses. Journal of Turkish Science Education, 8(1), 42-60.

Saleh, S. (2014). Malaysian students' motivation towards Physics learning. European Journal of Science and Mathematics Education, 2(4), 223-232.

Visser, Y. L. (2007). Convergence and divergence in children's attitudes towards the sciences and science education, Learning Development Institute, Florida Atlantic University.

Wei-Zhao, S. (2012). Gender, perception of learning physics and performance in university physics: A case study from China. Journal of Baltic Science Education, 11(3), 267-274.

Zavala, G., Millan, C., Dominguez, A., \& Gonzalez-Suarez, J. (2015). Students' perception of relevance of physics and mathematics in engineering. 122 nd ASEE Annual Conference \& Exposition, Seattle, WA. 